\title{
PEMURNIAN ASAP CAIR DARI KULIT DURIAN DENGAN MENGGUNAKAN ARANG AKTIF
}

\section{PURIFICATION OF LIQUID SMOKE FROM DURIAN PEEL'S WITH ACTIVATED CHARCOAL}

\author{
Adhitya Rinaldi ${ }^{1,2}$, Alimuddin², Aman Sentosa Panggabean ${ }^{2, *}$ \\ ${ }^{1}$ Balai Riset dan Standardisasi Industri Samarinda \\ ${ }^{2}$ Jurusan Kimia FMIPA Universitas Mulawarman \\ email: *amanspanggabean@yahoo.com
}

\begin{abstract}
ABSTRAK
Limbah kulit durian dapat diolah menghasilkan asap cair dan karbon aktif dengan metode pirolisis. Untuk menghasilkan asap cair yang dapat digunakan sebagai pengawet makanan, asap cair perlu di proses dengan metode pemurnian seperti destilasi, pemurnian dengan zeolit aktif dan arang aktif. Hasil karakterisasi asap cair dari kulit durian hasil pirolisis, destilasi, pemurnian dengan zeolit aktif dan pemurnian dengan arang aktif diperoleh nilai $\mathrm{pH}$ berturut-turut 4,09; 3,24; 3,46; dan 2,09. Kadar asam asetat berturut-turut 6,07; 7,59; 9,11; dan 10,63 (mg/L). Berdasarkan karakteristik komponen senyawa menggunakan GCMS asap cair hasil pirolisis terdeteksi 17 senyawa, asap cair hasil destilasi 12 senyawa, asap cair pemurnian zeolit aktif 10 senyawa dan asap cair pemurnian arang aktif 6 senyawa dengan mayoritas komponen senyawa terdiri dari asam asetat, fenol dan karbonil serta tidak mengandung senyawa karsinogenik, sehingga asap cair dari kulit durian dapat digunakan sebagai pengawet makanan.
\end{abstract}

Kata Kunci : Asap Cair, Karbon Aktif, Kulit Durian, Pemurnian

\begin{abstract}
Waste of durian's peel can be used to make liquid smoke and activated charcoal with pyrolysis method. To make liquid smoke for food preservative, liquid smoke must be proceeded with purification method such as distilation, purification with activated zeolit and activated charcoal. Liquid smoke characterization results from the durian's peel from pyrolysis, distillation, purification with activated zeolite and activated charcoal purification with $\mathrm{pH}$ values obtained successively $4.09 ; 3.24 ; 3.46$; and 2.09 . Acetic acid levels respectively $6.07 ; 7.59 ; 9.11$; and $10.63(\mathrm{mg} / \mathrm{L})$. Based on the characteristics of the component compounds using GC-MS, results of pyrolysis liquid smoke was detected 17 compounds, liquid smoke distillation obtaining 12 compounds, liquid smoke purification with active zeolit obtaining 10 compounds and liquid smoke from activated charcoal purification obtaining 6 compounds with the majority component comprised of acetic acid compounds, phenols and carbonyls and do not contain carcinogenic compounds, so it can be used as a food preservative.
\end{abstract}

Keywords : Active Charcoal, Durian's Peel, Liquid Smoke, Purification,

\section{PENDAHULUAN}

Durian merupakan salah satu buah yang sangat digemari dan banyak tumbuh di berbagai daerah di Indonesia. Dari sekitar 30 spesies yang ada di dunia, 20 spesies ditemukan di Kalimantan dan 7 spesies di Sumatera. Di Indonesia, produksi durian menempati urutan ke-4 setelah pisang, jeruk dan mangga dengan total produksi berkisar 388.806 sampai 797.798 ribu ton/ tahun (Badan Pusat Statistika, 2014). Selama ini buah durian 
hanya dapat dimanfaatkan dagingnya saja atau sekitar 20-35 persen dari seluruh bagian durian. Sementara sisanya sekitar 65-80 persennya terbuang sebagai limbah. Limbah kulit durian memiliki karakteristik yang sukar terurai sehingga berpotensi menjadi salah satu limbah hayati yang dapat menyebabkan pencemaran lingkungan (Saputra, 2013).

Kulit durian secara proporsional mengandung unsur selulosa yang tinggi (50-60\%) dan kandungan lignin (5\%), serta kandungan pati yang rendah $(5 \%)$ (Prabowo, 2009). Kulit durian dapat dimanfaatkan melalui proses pirolisis menghasilkan asap cair yang dapat digunakan sebagai bahan pengawet karena memiliki sifat antibakteri dan antioksidan (Wijaya dkk., 2008a). Sifat sebagai antibakteri ini berkaitan dengan kandungan senyawa-senyawa dalam asap cair, yaitu fenolik, senyawa karbonil, dan asam karboksilat. Penggunaan asap cair dapat diaplikasikan pada industri kayu seperti pengawetan kayu dan juga pada industri makanan sebagai pengawet pada ikan, daging dan bahan makanan lainnya (Sinha et al., 2000; Wijaya dkk., 2008 ${ }^{\mathrm{b}}$ ). Selain menghasilkan asap cair, pada proses pirolisis kulit durian juga menghasilkan arang yang dapat diaktivasi menjadi arang aktif.

Untuk menghasilkan asap cair grade 1 yakni asap cair yang dapat digunakan sebagai pengawet makanan, asap cair perlu dilakukan yakni dengan menggunakan proses destilasi, penyaringan dengan zeolit aktif dan penyaringan dengan menggunakan arang aktif yang diperoleh dari aktivasi arang hasil proses pirolisis kulit durian. Zeolit aktif digunakan untuk mendapatkan asap cair yang benar-benar bebas dari zat berbahaya seperti benzopiren. Sedangkan arang aktif bertujuan untuk mendapatkan filtrat asap cair dengan bau asap yang ringan dan tidak menyengat.
Untuk mengetahui kualitas dari asap cair yang dihasilkan, perlu dilakukan pengujian asam asetat dan fenol sebagai zat aktif yang berfungsi sebagai pengawet serta pengujian dengan menggunakan GCMS untuk mengetahui komponen kimia yang terdapat di dalam asap cair.

\section{METODE PENELITIAN}

\section{Alat dan Bahan}

Peralatan yang digunakan adalah : seperangkat alat pirolisis, alat destilasi, neraca analitik (Ohaus Mettler), Kromatografi Gas-Spektra Massa (GCMS, Shimadzu QP 2010), tabung reaksi, termometer, $\mathrm{pH}-$ Meter Orion model 420A, oven, desikator, pipet volumetrik, saringan, buret, gelas piala, Erlenmeyer, ayakan, alu, lumpang dan wadah sampel.

Bahan-bahan yang digunakan adalah kulit durian yang telah dipisahkan dari daging buah durian, sedangkan bahan kimia yang digunakan adalah : $\mathrm{NaOH}$, indikator $\mathrm{PP}, \mathrm{H}_{3} \mathrm{PO}_{4}, \mathrm{FeCl}_{3}$, zeolit aktif, karbon aktif dari kulit durian, larutan induk fenol, larutan buffer $\mathrm{pH} 4$, buffer $\mathrm{pH}$ 7, buffer $\mathrm{pH} 9$ dan akuades.

\section{Prosedur Penelitian}

\section{Preparasi Sampel}

Sampel kulit durian sebelum diproses menjadi asap cair, dilakukan proses preparasi. Kulit durian dibersihkan dari daging buah durian, selanjutnya kulit durian dicacah hingga ukuran 2-3 cm, kemudian dikeringkan di bawah sinar matahari.

\section{Analisis Kadar Air Kulit Durian}

Ditimbang cawan kosong yang akan digunakan sebagai wadah kulit durian, lalu diambil beberapa gram kulit durian dan ditimbang bersama cawan kosong. Selanjutnya kulit durian dikeringkan di dalam oven pada temperatur $105{ }^{\circ} \mathrm{C}$ selama 1 jam. Kulit durian yang telah dikeringkan dimasukkan ke dalam desikator untuk didinginkan, kemudian 
ditimbang bobot kulit durian bersama cawan.

\section{Proses Pembuatan Asap Cair}

Disiapkan seperangkat alat pirolisis, lalu dimasukkan kulit durian ke dalam alat pirolisis. Proses pirolisis dilakukan hingga suhu $\pm 400{ }^{\circ} \mathrm{C}$, lalu ditampung destilat asap cair yang dihasilkan ke dalam wadah sampel. Proses pirolisis dilakukan hingga tidak ada lagi destilat asap cair yang keluar. Volume asap cair yang dihasilkan dicatat dan diukur bobot arang kulit durian yang terbentuk. Selanjutnya destilat asap cair didiamkan selama 1 minggu untuk mengendapkan ter.

\section{Proses Aktivasi Arang}

Arang hasil proses pirolisis diaktivasi secara fisika-kimia. Arang ditumbuk dan disaring dengan saringan ukuran 80 mesh, kemudian arang yang terbentuk direndam dalam larutan $\mathrm{H}_{3} \mathrm{PO}_{4}$ dengan konsentrasi 9 $\%(\mathrm{v} / \mathrm{v})$, dengan perbandingan 1:15 dalam gelas piala selama 22 jam kemudian disaring. Selanjutnya arang dikeringkan dalam oven pada suhu $110^{\circ} \mathrm{C}$.

\section{Proses Pemurnian Asap Cair dengan Destilasi}

Asap cair yang dihasilkan
dimurnikan dengan cara destilasi
menggunakan alat destilasi pada suhu 150
${ }^{\circ} \mathrm{C}$ hingga terpisah antara cairan coklat
yang mengandung ter dengan destilat yang
bewarna bening.

\section{Proses Pemurnian Asap Cair dengan Zeolit Aktif} menggunakan zeolit aktif dengan cara mengalirkan asap cair destilat ke dalam kolom zeolit aktif sehingga diperoleh filtrat asap cair.

\section{Proses Pemurnian Asap Cair dengan Arang Aktif}

Filtrat asap cair dari filtrasi zeolit aktif difiltrasi kembali menggunakan arang aktif yang berasal dari arang kulit durian yang telah diaktivasi. Filtrat asap cair dimasukkan ke dalam kolom yang berisi karbon aktif kemudian filtrat yang didapatkan ditampung di dalam wadah untuk dilakukan pengujian.

\section{Pengukuran pH Asap Cair}

Asap cair yang dihasilkan dari proses pirolisis, destilasi, filtrasi zeolit aktif dan filtrasi arang aktif diukur kadar keasamannya $(\mathrm{pH})$ menggunakan alat $\mathrm{pH}$ meter yang telah terkalibrasi.

\section{Analisis Kandungan Asam Asetat dalam Asap Cair}

Diambil 0,2 $\mathrm{mL}$ asap cair lalu ditambahkan akuades sampai volume 100 $\mathrm{mL}$. Selanjutnya ditambahkan indikator PP lalu dititrasi dengan larutan $\mathrm{NaOH} 0,1 \mathrm{~N}$. Volume $\mathrm{NaOH}$ yang digunakan untuk titrasi dicatat dan dihitung kandungan asam asetat dalam asap cair.

\section{Analisis Kualitatif Senyawa Fenol dalam Asap Cair}

Diambil 0,5 gram asap cair hasil pirolisis, destilasi, pemurnian dengan zeolit aktif dan pemurnian dengan arang aktif lalu dilarutkan dalam $5 \mathrm{~mL}$ aquades dan dipanaskan hingga mendidih. Setelah itu ditambahkan beberapa tetes $\mathrm{FeCl}_{3}$ dan diamati perubahan warna yang terjadi.

\section{Analisis Kandungan Asap Cair dengan GC MS}

Sampel asap cair hasil pirolisis, destilasi, pemurnian dengan zeolit aktif dan pemurnian dengan arang aktif selanjutnya dianalisis menggunakan Kromatografi Gas-Spektra Massa (GC$\mathrm{MS})$ untuk mengetahui kandungan senyawa yang ada di dalam asap cair tersebut.

\section{HASIL DAN PEMBAHASAN}

Asap cair merupakan dispersi uap asap dalam udara yang dihasilkan dari proses distilasi kering atau biomassa 
seperti kayu, kulit kayu, tempurung, sabut, bambu, daun dan lain sebagainya. Proses pirolisis ini berjalan secara bertahap diawali dari tahap pertama penghilangan air biomassa pada suhu $120-150{ }^{\circ} \mathrm{C}$, diikuti tahap kedua proses pirolisis hemiselulosa pada suhu $150-200{ }^{\circ} \mathrm{C}$, kemudian tahap ketiga proses pirolisis selulosa pada suhu 250-300 ${ }^{\circ} \mathrm{C}$, dilanjutkan tahap ke empat proses pirolisis lignin pada suhu $400{ }^{\circ} \mathrm{C}$ (Maga, 1987; Sinha et al., 2000). Sebelum dilakukan proses pirolisis kulit durian, dilakukan terlebih dahulu pengukuran kadar air kulit durian yang digunakan. Dari pengukuran kadar air kulit durian secara gravimetri, diperoleh nilai kadar air sebesar 58,91\%. Kadar air dapat memberikan variasi terhadap komposisi asap. Jumlah kadar air yang meningkat menyebabkan kadar fenol yang rendah dan meningkatkan kadar karbonil.

Destilasi merupakan proses pemisahan berdasarkan perbedaan titik didih dari komponen-komponen yang akan dipisahkan, pemekatan larutan dan juga pemurnian komponen cair. Proses pemurnian asap cair dengan destilasi dilakukan pada suhu $150{ }^{\circ} \mathrm{C}$, dengan asumsi bahwa senyawa-senyawa $\mathrm{PAH}$ seperti benzopirene dengan titik didih yang tinggi serta tar akan tertinggal sebagai residu sehingga senyawa-senyawa lain seperti fenol, karbonil dan asam dengan titik didih yang rendah akan terpisah menjadi destilat (Guillen et al., 2000).

Pada proses destilasi ini, sampel asap cair yang berwarna kecoklatan akan terpisah dan menghasilkan destilat yang berwarna kuning. Perubahan warna tersebut karena fenol dan karbonil yang memiliki sifat pengawet yang tinggi terpisah dengan senyawa-senyawa karsinogenik seperti PAH dan tar. Asap cair yang sudah mengalami proses destilasi dilewatkan melalui zeolit aktif.
Sampel asap cair hasil destilasi yang pada awalnya berwarna kuning keruh setelah dilewatkan melalui zeolit aktif berubah menjadi berwarna kuning jernih dengan aroma asap yang berkurang. Proses pemurnian ini menyebabkan senyawa berbahaya seperti benzopirene dan tar yang terdapat di dalam asap cair teradsorpsi oleh zeolit aktif. Residu arang hasil proses pirolisis kemudian diaktivasi secara fisika dan kimia sehingga menjadi arang aktif yang selanjutnya digunakan untuk proses akhir pemurnian asap cair.

Arang yang diperoleh dari proses pirolisis diaktivasi dengan cara kimia, yakni dengan cara merendam arang yang telah digerus ke dalam larutan $\mathrm{H}_{3} \mathrm{PO}_{4} 9 \%$ selama 22 jam. Perendaman dimaksudkan untuk memperbesar pori-pori arang sehingga dapat menyerap lebih banyak zat organik dan kandungan logam di dalam asap cair. Menurut Darmadji (2002) penggunaan arang aktif pada asap cair hasil destilasi untuk menurunkan benzopirene dan bau yang menyengat. Asap cair yang berasal dari proses pemurnian zeolit aktif dimurnikan kembali dengan arang aktif yang berasal dari rendemen arang hasil pirolisi yang telah diaktivasi sehingga asap cair menjadi tidak berwarna dan juga menghilangkan bau menyengat.

\section{Analisis pH Asap Cair}

$\mathrm{pH}$ asap cair dari berbagai proses pemurnian asap kulit durian sangat dipengaruhi oleh asam asetat atau fenol yang terdapat dalam asap cair tersebut. Nilai pH merupakan salah satu parameter kualitas dari asap cair yang dihasilkan. Senyawa asam asetat dapat mempengaruhi $\mathrm{pH}$ asap cair dan citarasa serta umur simpan produk asapan. Selain itu kadar fenol juga mempengaruhi $\mathrm{pH}$ dari asap cair karena fenol memiliki sifat asam yang merupakan pengaruh dari cincin aromatisnya (Wijaya dkk., 2008 ${ }^{\mathrm{a}}$ ). 
Tabel 1. Nilai pH Asap Cair Hasil Proses Pirolisis, Pemurnian dengan Destilasi, Zeolit Aktif, dan Arang Aktif

\begin{tabular}{lll}
\hline Kode Sampel & pH & Suhu $\left({ }^{\circ} \mathbf{C}\right)$ \\
\hline Hasil Proses Pirolisis & 4,09 & 28,1 \\
Hasil Proses Destilasi & 3,24 & 28,1 \\
Pemurnian dengan Zeolit Aktif & 3,46 & 28,2 \\
Pemurnian dengan Arang Aktif & 2,09 & 28,2 \\
\hline
\end{tabular}

Berdasarkan Tabel 1 terdapat kecenderungan penurunan nilai $\mathrm{pH}$ dari asap cair hasil pirolisis dengan hasil pemurnian dengan arang aktif. Hal ini disebabkan karena kandungan senyawa asam asetat dan fenol yang terus meningkat selama proses pemurnian. Semakin tinggi kadar total fenol dalam asap cair maka nilai pH-nya semakin rendah atau bersifat asam. Kenaikan temperatur pembakaran selama proses pirolisis dapat mempengaruhi nilai $\mathrm{pH}$ dari asap cair. Hal ini dikarenakan komponen limbah kulit durian yang menghasilkan asam organik dan homolognya, yaitu hemiselulosa dan selulosa mengalami pirolisis pada temperatur pembakaran di atas $300^{\circ} \mathrm{C}$ dan menghasilkan asam-asam organik dan fenol, sehingga pHnya menurun. (Guillen et al., 1996; Sinha et al., 2000)
Nilai $\mathrm{pH}$ asap cair akan semakin menurun seiring dengan naiknya temperatur destilasi. Semakin menurunnya nilai $\mathrm{pH}$, akan semakin tinggi kadar asam yang terkandung di dalam asap cair (Lombok et al., 2014).

\section{Analisis Asam Asetat Asap Cair}

Kadar asam yang dihitung adalah kadar asam asetat yang merupakan komponen penting di dalam asap cair. Hasil pengamatan kadar asam menunjukkan bahwa asap cair kulit durian memiliki kadar asam yang lebih besar pada temperatur pembakaran yang lebih tinggi. Perbedaan jumlah kadar asam ini dikarenakan asam organik yang dihasilkan dari dekomposisi komponen hemiselulosa berupa heksosan dan selulosa mengalami pirolisis lebih sempurna pada temperatur pembakaran yang lebih tinggi.

Tabel 2. Data Hasil Analisis Asam Asetat Asap Cair

\begin{tabular}{lc}
\hline Kode Sampel & Kadar Asam (mg/L) \\
\hline Hasil Proses Pirolisis & 6,07 \\
Hasil Proses Destilasi & 7,59 \\
Pemurnian dengan Zeolit Aktif & 9,11 \\
Pemurnian dengan Arang Aktif & 10,63 \\
\hline
\end{tabular}

Kadar asam asetat yang diperoleh dari sampel asap cair mengalami kenaikan setelah dilakukan perlakuan-perlakuan pemurnian baik dengan destilasi, pemurnian dengan zeolit aktif dan pemurnian arang aktif. Hal ini sesuai dengan kecenderungan nilai yang diperoleh dari pengukuran $\mathrm{pH}$ menggunakan alat $\mathrm{pH}$ meter. Semakin besar konsentrasi asam yang diperoleh, maka nilai $\mathrm{pH}$ yang didapat juga semakin kecil.

\section{Uji Bau Asap Cair}

Bau merupakan salah satu faktor pendukung cita rasa yang menentukan kualitas suatu produk. Timbulnya aroma atau bau ini karena zat bau tersebut bersifat volatile (mudah menguap), sedikit larut dalam air dan lemak.

Asap cair yang diperoleh dari proses pirolisis, pemurnian dengan destilasi, zeolit aktif dan arang aktif dilakukan uji bau pada 
20 orang responden. Uji bau asap cair yang dilakukan berdasarkan kriteria nilai;

$1=$ asap cair tidak berbau,

$2=$ asap cair kurang berbau,

3 = asap cair kurang menyengat,

$4=$ asap cair bau menyengat,

5 = asap cair bau sangat menyengat.
Berdasarkan pada kriteria bau tersebut diperoleh nilai uji bau pada asap cair kulit durian hasil proses pirolisis, destilasi, pemurnian dengan zeolit aktif dan pemurnian dengan arang aktif seperti pada Gambar 1.

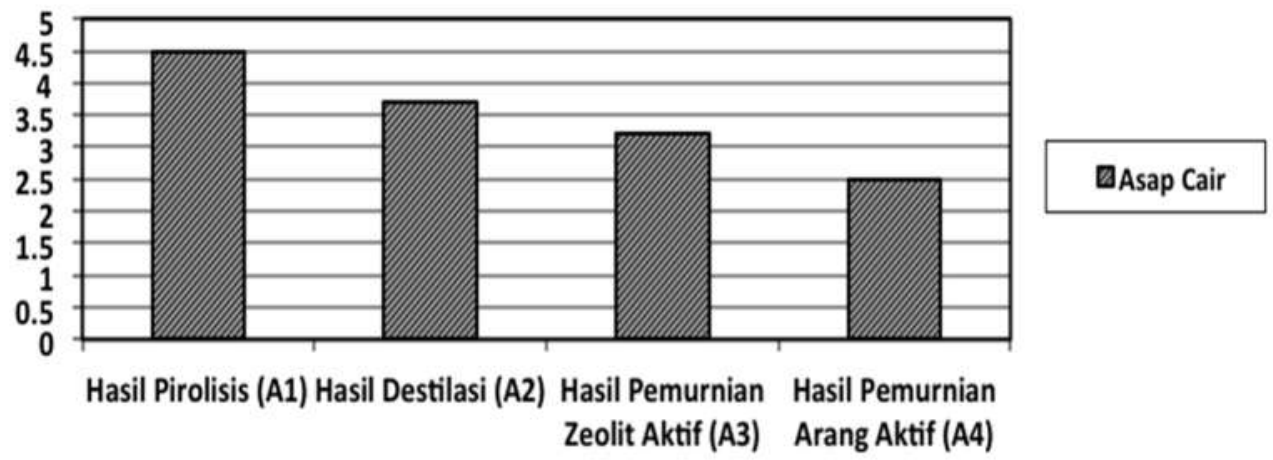

Gambar 1. Uji Bau Asap Cair

Dari hasil uji organoleptik abu asap cair hasil pirolisis, destilasi, pemurnian zeolit aktif dan arang aktif diketahui bahwa panelis memberikan nilai sangat menyengat untuk asap cair hasil pirolisis dan berturut-turut nilai yang diperoleh semakin kecil seiring dengan perlakuan pemurnian yang diberikan.

Aroma asap yang terbentuk sebagian besar dipengaruhi oleh adanya senyawa fenol dan karbonil serta sebagian kecil juga dipengaruhi oleh asam. Senyawa fenol yang berperan sebagai salah satu penyumbang bau asap terdiri dari fenol dengan titik didih tinggi dan fenol dengan titik didih rendah (Darmadji, 2002). Pada saat proses pirolisis dengan suhu tinggi maka akan terbentuk senyawa-senyawa fenol dengan titik didih tinggi. Namun setelah dilakukan proses destilasi, senyawa-senyawa fenol dengan titik didih tinggi akan terpisah dengan destilat sehingga hanya senyawa-senyawa fenol dengan titik didih rendah saja yang terdapat dalam destilat. Hal tersebut yang mengurangi bau dari asap cair proses destilasi. Selanjutnya dengan dilakukannya proses pemurnian dengan zeolit aktif dan arang aktif, akan mengurangi tingkat kebauan dari asap cair karena adanya senyawa-senyawa yang ditangkap oleh zeolit aktif dan arang aktif sehingga asap cair terakhir hasil proses pemurnian dengan arang aktif memiliki bau yang tidak menyengat. Kualitas asap cair ditentukan oleh komponen kimia yang terkandung di dalamnya karena dapat mempengaruhi rasa dan aroma asap cair (Haji dkk., 2012).

\section{Uji Warna Asap Cair}

Asap cair yang diperoleh dari proses pirolisis, pemurnian dengan destilasi, zeolit aktif dan arang aktif dilakukan uji warna pada 20 orang responden. Uji warna asap cair yang dilakukan berdasarkan kriteria nilai;

$1=$ tidak berwarna,

$2=$ kekuningan,

$3=$ kuning,

$4=$ coklat,

$5=$ hitam

Berdasarkan pada kriteria tersebut warna diperoleh nilai uji warna pada asap cair kulit durian hasil proses pirolisis, destilasi, pemurnian dengan zeolit aktif dan pemurnian dengan arang aktif seperti pada Gambar 2. 


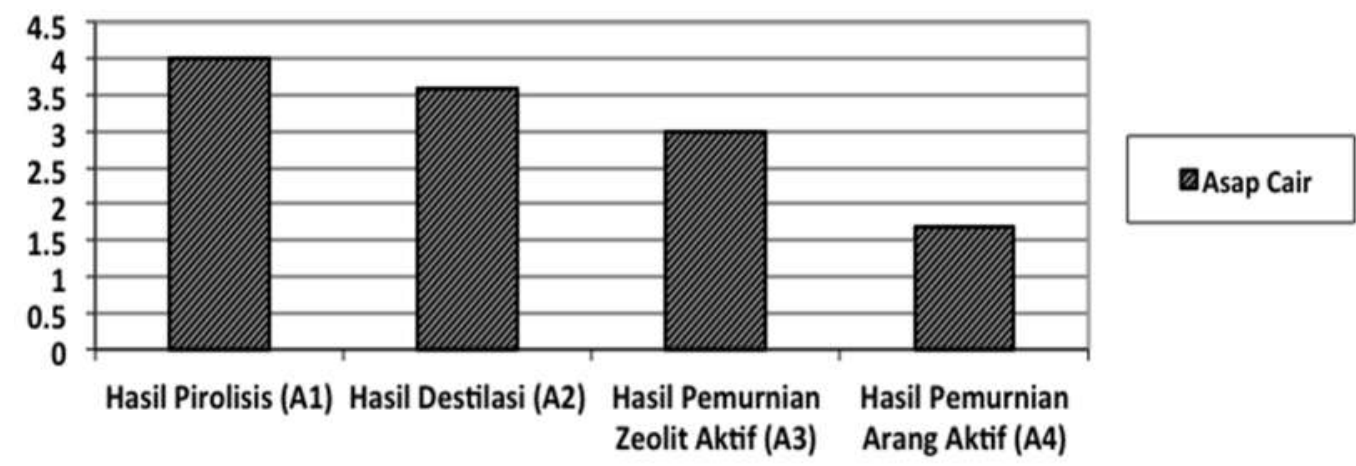

Gambar 2. Grafik Uji Warna Asap Cair

Pada pengujian organoleptik warna, menunjukkan bahwa asap cair hasil pirolisis berwarna kuning kecoklatan, pada hasil destilasi warna asap cair berwarna kuning keruh. Sedangkan warna pada hasil pemurnian zeolit aktif dan arang aktif berturut-turut adalah kuning jernih dan tidak berwarna. Asap cair yang awalnya berwarna kuning keruh berubah menjadi berwarna kecoklatan. Hal tersebut dapat disebabkan karena terjadinya proses oksidasi senyawa fenolat di dalam asap cair sehingga perlu dilakukan pengemasan asap cair pada wadah tertutup berwarna gelap untuk mengurangi terjadinya oksidasi pada asap cair.

\section{Analisis Kualitatif Fenol Asap Cair}

Senyawa fenol sangat penting dalam produk asap, karena fenol berperan dalam menyumbangkan aroma dan rasa spesifik pada produk asap. Fenol dengan titik didih yang lebih tinggi akan menunjukkan sifat antioksidan yang lebih baik jika dibandingkan dengan senyawa fenol yang bertitik didih rendah (Pszczola, 1995). Fenol juga bekerja secara sinergis dengan asam dan karbonil sebagai anti mikroba sehingga dapat menghambat peruraian dan pembusukan produk yang diasap.

Dari hasil analisis kualitatif fenol dalam asap cair, dibandingkan dengan larutan fenol diperoleh hasil asap cair positif mengandung senyawa fenol yang ditandai dengan terbentuknya warna kuning pada larutan setelah diteteskan larutan $\mathrm{FeCl}_{3}$.

\section{Analisis Asap Cair dengan GC-MS}

Analisis GC-MS dilakukan untuk mengetahui jenis-jenis senyawa yang terdapat pada asap cair. Komponenkomponen senyawa yang terdapat dalam asap cair yang dihasilkan dari berbagai proses dapat dilihat pada Tabel 3 .

Dari Tabel 3. hasil pengukuran GCMS asap cair dari proses pirolisis terdapat 17 senyawa yang merupakan hasil proses dekomposisi tiga komponen utama dari kulit durian, yakni selulosa, hemiselulosa dan lignin. Setelah dilakukan proses pirolisis, dilanjutkan dengan proses destilasi. Dapat dilihat bahwa senyawa asam asetat mengalami peningkatan konsentrasi setelah dilakukan pemurnian dengan proses destilasi. Hal tersebut terjadi kemungkinan disebabkan terdapatnya senyawa-senyawa dengan titik didih tinggi yang tidak teruapkan menjadi destilat, sehingga persentase dari asam asetat menjadi bertambah besar. Senyawa kimia dominan yang keberadaannya selalu ada pada ketiga asap cair hasil pirolisis dan hasil pemurnian dengan proses distilasi adalah asam asetat dan fenol. Senyawa fenol dan asam asetat ini sangat berperan dalam menghambat pertumbuhan mikroba.

Hasil analisis GC-MS dari proses pemurnian dengan zeolit aktif dan arang aktif memperlihatkan bahwa komponen asam asetat merupakan senyawa yang paling dominan yang terkandung dalam asap cair kulit durian. Kadar asam asetat semakin bertambah seiring dengan proses 
pemurnian yang dilakukan. Hal ini disebabkan karena besarnya kadar selulosa dan hemiselulosa. Selulosa dan hemiselu- losa akan membentuk asam asetat dan homolognya setelah dilakukan reaksi pirolisis.

Tabel 3. Data Pengukuran GC-MS Sampel Asap Cair yang Dihasilkan dari berbagai proses

\begin{tabular}{|c|c|c|c|c|}
\hline \multirow[b]{2}{*}{ Nama Senyawa } & \multicolumn{4}{|c|}{$\%$ Area } \\
\hline & Pirolisis & Destilasi & $\begin{array}{c}\text { Pemurnian } \\
\text { dengan Zeolit } \\
\text { Aktif }\end{array}$ & $\begin{array}{c}\text { Pemurnian dengan } \\
\text { Arang Aktif dari } \\
\text { Kulit Durian }\end{array}$ \\
\hline 1,2-Etandiol & 5,02 & 4,46 & 1,56 & - \\
\hline 2-Propanon & 6,23 & 2,27 & 1,77 & - \\
\hline 2-Butanon & - & 3,90 & 0,80 & - \\
\hline Tetrahidrofuran & - & 3,99 & 6,56 & - \\
\hline Metil asetat & 2,18 & - & - & - \\
\hline 1-Propanol & 0,68 & - & - & - \\
\hline 2-Butanon & 6,51 & - & - & - \\
\hline 2-Hidroksitetrahidrofuran & 2,53 & - & - & - \\
\hline Vinil asetat & - & - & - & 1,79 \\
\hline Asam asetat & 54,12 & 60,29 & 62,15 & 66,47 \\
\hline 2-Pentanon & 1,50 & - & - & - \\
\hline 1-Propoksi-2-propanol & 2,2 & - & - & - \\
\hline 3-Hidroksi-2-butanon & - & 2,05 & - & - \\
\hline Asam propionat & 1,17 & 1,75 & 3,27 & 4,43 \\
\hline 3-Penten-2-on & 0,26 & - & - & - \\
\hline Siklopentanon & 1,70 & 1,74 & - & - \\
\hline 2-Furankarboksaldehyde & 6,68 & 7,03 & 9,78 & 12,15 \\
\hline 2-Siklopenten-1-on & 1,30 & 2,46 & 1,95 & - \\
\hline Fenol & 1,38 & 2,91 & 2,94 & 3,18 \\
\hline o-Kresol & 1,45 & - & - & - \\
\hline Guaiakol & 5,10 & 7,15 & 9,22 & 11,98 \\
\hline
\end{tabular}

\section{KESIMPULAN}

Asap cair dari kulit durian yang dibuat dari proses pirolisis, pemurnian secara destilasi, pemurnian dengan zeolit aktif dan pemurnian dengan arang aktif, diperoleh nilai $\mathrm{pH}$ berturut-turut 4,09; 3,24; 3,46; dan 2,09. Kadar asam asetat berturut-turut 6,$07 ; 7,59 ; 9,11$ dan 10,63 $(\mathrm{mg} / \mathrm{L})$. Dari data kromatogram dari pengukuran dengan GC-MS terdapat 17 senyawa pada asap cair hasil pirolisis, 12 senyawa pada asap cair hasil destilasi, 10 senyawa pada asap cair pemurnian dengan zeolit aktif dan 6 senyawa asap cair pemurnian dengan arang aktif. Asap cair dari kulit durian hasil proses pemurnian dengan arang aktif yang berasal dari kulit durian dapat digunakan sebagai pengawet makanan karena di dalam asap cair tidak mengandung senyawa karsinogenik seperti tar dan benzopirene.

\section{DAFTAR PUSTAKA}

Badan Pusat Statistik. 2014. Produksi Buah-buahan Menurut Provinsi (Ton), http://www.bps.go.id.

Darmadji, P. 2002. Optimasi Pemurnian Asap Cair dengan Metoda Redestilasi. Jurnal Teknologi dan Industri Pangan. Vol. 13(3). Hal. $267-271$. 
Guillen, M.D. and Ibargoita, M.I. 1996. Relationship between the maximum temperature reached in the smoke generation process from Vitis viniera $L$. Shoot sawdust and composition of the aquaeus smoke flavoring preparation obtained. J. Agric. Food. Chem. 44. pp. 1302-1307.

Guillen, M.D., Sopelana, P., and Partearroyo, M.A. 2000. Polycyclic aromatic hydrocarbons in liquid smoke flavorings obtained from different types of wood, effect of storage in polyethylene flasks on their concentrations. J. Agric. Food Chem. 48. pp. 5083-6087.

Haji, A.G., Mas'ud, Z.A., dan Pari, G. 2012. Identifikasi Senyawa Bioaktif Antifeedant Dari Asap Cair Hasil Pirolisis Sampah Organik Perkotaan. Jurnal Bumi Lestari. Vol. 12(1). Hal. 1-8.

Lombok, J.Z., Setiaji, B., Trisunaryanti, W. and Wijaya, K. 2014. Effect of Pyrolisis Temperature and Distilliation on Character of Coconut Shell Liquid Smoke. Asian Journal of Science and Technology. Vol. 5(6). pp. 320-325

Maga, J.A. 1987. Smoke in Food Processing. Baca Raton. CRC Press. Florida.
Prabowo, R. 2009. Pemanfaatan Limbah Kulit Buah Durian Sebagai Produk Briket di Wilayah Kecamatan Gunung Pati Kabupaten Semarang. Jurnal Mediagro Ilmu-Ilmu Pertanian. Vol 5(1). 52-57.

Pszczola, D.E. 1995. Tour Highlights Production And Users of Smoke Based Flavors. Food Technology. 1. pp. 70-74.

Saputra, F.D. 2013. Asap Cair dari Kulit Durian Pengawet Alami Untuk Pangan. Media BPP. Vol. 12(6). Hal. 3-10.

Sinha, H., Jhalani, A., Ravi, M, R. and Ray, A. 2000. Modelling of Pyrolysis in Wood: Review. Solar Energy Society of India Journal. Vol. 10(1). pp. 41-62

Wijaya, M., Noor, E., Irawadi, T.T. dan Pari, G. 2008 ${ }^{\mathrm{a}}$. Karakterisasi Komponen Kimia Asap Cair dan Pemanfaatannya sebagai Biopestisida. Jurnal Bionature. Vol 9(1). Hal. 34-40.

Wijaya, M., Noor, E., Irawadi, T.T. dan Pari, G. 2008 . Perubahan suhu pirolisis terhadap struktur kimia asap cair dari serbuk gergaji kayu pinus. Jurnal Hasil Hutan. 1(2) Hal. 73-77. 